\title{
Legitimating status: perceptions of meritocracy and inequality among undergraduates at an elite British university
}

\section{Citation}

Warikoo, Natasha Kumar., and Christina Fuhr. 2014. Legitimating status: Perceptions of meritocracy and inequality among undergraduates at an elite British university. British Educational Research Journal 40, no. 4: 699-717.

\section{Published Version}

doi:10.1002/berj.3108;http://onlinelibrary.wiley.com/doi/10.1002/berj.3108/abstract

\section{Permanent link}

http://nrs.harvard.edu/urn-3:HUL.InstRepos:23922467

\section{Terms of Use}

This article was downloaded from Harvard University's DASH repository, and is made available under the terms and conditions applicable to Open Access Policy Articles, as set forth at http:// nrs.harvard.edu/urn-3:HUL.InstRepos:dash.current.terms-of-use\#OAP

\section{Share Your Story}

The Harvard community has made this article openly available.

Please share how this access benefits you. Submit a story.

\section{Accessibility}




\section{Legitimating Status: Perceptions of Meritocracy and Inequality among Undergraduates at an Elite British University}

Appeared in British Education Research Journal, 2014.

Natasha Kumar Warikoo

Harvard University Graduate School of Education, Cambridge, MA

6 Appian Way, 4th Floor

Cambridge, MA 02138

United States

(+1) (617) 495-2488

Natasha_warikoo@gse.harvard.edu

Christina Fuhr

University of Oxford Department of Sociology, Oxford, UK

(+44) 07506511435

Christina.fuhr@stcatz.ox.ac.uk

\section{Acknowledgements}

We thank Ruben Gaztambide-Fernandez, Anna Zimdars, Daniel Sabbagh, and reviewers for British Education Research Journal for helpful comments on previous versions of this article. Funding for this research was provided by the British Academy. 


\title{
Legitimating Status: Perceptions of Meritocracy and Inequality among Undergraduates at an Elite British University
}

\begin{abstract}
Given the frequent critiques of elite universities for admitting low numbers of state-school graduates and, more recently, British Afro-Caribbean students, how do students attending those universities make meaning of the admissions process? Through an analysis of 46 one-on-one in-depth interviews with undergraduates attending Oxford University, we show that students believe in the fairness of the admissions process, while lamenting the lack of opportunities for educational advancement faced by some disadvantaged youth in British society. Despite their understanding that many British youth do not have access to educational experiences that make Oxbridge an attainable goal, most students do not support changes to make access more equitable across class or racial/ethnic lines. This perspective, which legitimates the status students gain through matriculation at an elite university, supports the maintenance of unequal access to an Oxford education despite the advantages that education is known to confer to graduates. The findings demonstrate elites acknowledging the disadvantages of particular groups in society without acknowledging their own advantages in the same system. They do so by recognizing two elements of merit: (1) intelligence, which most students assume led to their own admission; and (2) cultivation of that intelligence, which requires elite secondary schools and which most students see as disadvantaging particular groups in society. In the paper we highlight differences in meaning-making between graduates of grammar, comprehensive, and private schools.
\end{abstract}

Keywords: higher education, elites, meritocracy, multiculturalism 


\section{Legitimating Status: Perceptions of Meritocracy and Inequality among Undergraduates at an Elite British University}

Modern Western societies operate on the premise that status is achieved rather than inherited. Meritocracy —a system in which rewards are distributed based on individual merit rather than, for example, inheritance or payment—serves to legitimate the status hierarchy in modern industrial democracies, in contrast to the inherited and coercive dominance of elites in traditional societies (Bourdieu and Passeron 1977; Weber 1968; Young, 1958). Lipset and Bendix (1992) argue that social mobility in fact characterizes modern industrial societies. The status attainment literature documents just how much social mobility takes place by showing that education level is associated with adult earnings independent of parents' level of education (Blau \& Duncan, 1967). Still, the degree to which individuals can actually change their social status has been questioned by many (Bourdieu 1984; Bowles and Gintis 1976; Karabel and Halsey 1977). Michael Young, in the book that coined the term 'meritocracy' (1958), warned against a system in which elites use notions of "merit” to reproduce status and hence to sustain inequality in society.

The education system is a key site through which meritocracy is legitimated while simultaneously status is reproduced (Bourdieu and Passeron 1977). Early research focuses thereby on schools. Bourdieu and Passeron (1977) demonstrate how schools maintain society's status hierarchy and consequent inequalities by expecting an unspoken set of behaviors, dispositions, and styles for success in school. These tastes, behaviors, and dispositions—cultural capital—are internalized by high status children from their parents and are not explicitly taught in school but are necessary for school success and consequently for status attainment. Overall, we also know that adults' levels of education are correlated to the degree to which they perceive social rewards to be fairly distributed on the basis of merit; those with higher levels of education are more likely to believe that their country is a meritocracy (Duru-Bellat and Tenret 2012).

Studies focusing on higher education show that only those who are successful in the stratified education system have the chance to attend elite universities and thus are able to achieve elite status, and 
that success is mediated by family background (Archer, Hutchings, and Ross 2003; Reay, David, and Ball 2005; Shiner and Modood 2002). Furthermore, access to information on higher education and the application process is mediated by social class (Archer, Hutchings, and Ross 2003; Reay, David, and Ball 2005). Recent research has also shown that among applicants to Oxford University, cultural capital plays a significant role in many admissions decisions (Zimdars, Sullivan, and Heath 2009). ${ }^{\mathrm{i}}$ Once students matriculate, elite universities promote the creation and perpetuation of elite status in their students, through (1) constructing social categories such as “Oxbridge graduate” that provide advantages on the job market and in politics; and (2) promoting the notion that their graduates have important qualities that differentiate them from non-graduates (Collins, 1979; Kamens 1977; Meyer, 1977). In Britain, the notion of an Oxbridge graduate's intellectual qualities and qualifications for leadership in society extend well beyond the campus walls to the larger society, and hence matriculation symbolically endows students with membership in that high status group.

Both the status attainment (Blau and Duncan 1967; Lipset and Bendix 1992) and the reproduction (Bourdieu and Passeron 1977; Willis 1977) models of education emphasize the degree to which structural opportunities and barriers exist or do not exist in education (Davies 1995; Stevens 2008). Neither of these prominent perspectives, however, focuses on how individual actors make meaning of their place in educational institutions. In spite of the rich body of research on admissions and access to higher education in Britain, studies have not yet analyzed how students themselves make meaning of their success in the admissions contest to elite higher education. Not only institutions but also the individuals that institutions and gatekeepers reward have an interest in maintaining the legitimacy of the criteria for success in the institution. ${ }^{\text {ii }}$ In order to embrace their elite status students attending elite universities must maintain the legitimacy of the contest for admission despite well-publicized inequalities in who attends their university related to school-type (state or private) and race (for example, see Harris 2010; Lammy 2010; Parel and Ball 2013; Vasagar 2010b). What do those who succeed in admission to elite British universities make of their status position, especially given the disproportionate number of students from advantaged backgrounds? 
Many Oxbridge graduates will go on to leadership roles in society, with considerable decisionmaking power. For example, a recent study found that in Britain $62 \%$ of elites in the diplomatic service are graduates of Oxbridge, as are 58\% of elite lawyers and 55\% of those with top civil service positions (Sutton Trust, 2012). At Oxford in particular, 18\% of Britain’s Houses of Parliament are alumnae of Oxford (Vasagar, 2010a). Hence, the perspectives of students in this study will have real, significant effects on future decision-making regarding access to and the opening up of elite higher education to underrepresented groups in Britain. Accordingly, this article will provide nuanced insights not only into how status but also the social inequalities it produces are perpetuated in society.

This paper analyzes Oxford undergraduates’ meaning-making of university admissions through an analysis of 46 in-depth one-on-one in-depth interviews with undergraduates at Oxford University. We analyze not only students’ perceptions of the fairness of Oxford's admissions process but also their explanations for why some groups are underrepresented in the student body and what, if anything, should change about that process. The findings show how the perspectives of elite actors can serve to legitimate and, consequently, perpetuate a system of meritocracy whose outcomes are stratified by race, class, and school-type.

The narratives below show students working to maintain and defend their elite status, through maintaining the legitimacy of the process by which they attained elite status and by rejecting potential university practices that might suggest an alternative process. They do this within a social context that forcefully challenges the legitimacy of the admissions process. These threats to the legitimacy of their status may in fact heighten the desire to legitimate that status (Jackman and Muha 1984). Two rationales constitute their meaning-making. First, most students describe the admissions process as meritocratic and reject the tradition of inherited status. Some, especially private school graduates, state this unconditionally, with little hesitation. Second, those who acknowledge the dearth of state school graduates and minority students either suggest that underrepresented students are choosing not to apply or matriculate, or else they define meritocracy as being constituted not only by intelligence but also by skills that are best cultivated in private school settings, accounting for the overrepresentation of private school 
graduates. These views allow students to maintain a sense of accomplishment in their status and accordingly their sense of self-worth in an elite, competitive institution. ${ }^{\text {iii }}$ This second rationale conceptualizes the university as static, such that prospective students must conform to the cultural and academic expectations there, rather than a dynamic one that responds to the needs of a changing student body comprised of a diverse set of meritous students.

When asked to explain the underrepresentation of black ${ }^{\text {iv }}$ students at Oxford, students in our study do acknowledge secondary schooling inequality in British society and the effect this has on admissions. Very public debates highlight the underrepresentation of state school graduates and of British Afro-Caribbean students at top British universities like Oxford, and most students across class and race lines made their knowledge of this inequality known. Hence, their elite perspectives are considerably more nuanced in their acknowledgement of inequality of opportunities than status reproduction theories might predict. Nevertheless, most students acknowledged only the minimum necessary to explain stratification in admissions. Notably, although they could mention the disadvantages resulting in some groups not attaining the skills necessary to succeed at Oxford, they did not make connections to the advantages that led them to succeed. Furthermore, students generally could not think of university policies to decrease the social stratification they acknowledged, and they did not support suggested ones. This finding resonates with other research showing that those with advantages in society can be willing to acknowledge others' disadvantages and lament them while simultaneously disagreeing with social policies that would remedy those disadvantages (Bell and Hartmann 2007; Bobo and Kluegel 1993; Citrin et al. 2001; Quillian 2006; Schuman, Steeh, and Bobo 1997). Rather than resulting from feelings of group threat, however, as the literature on racial inequality and multiculturalism suggests, we find that the motivation to legitimate status seems to underlie the disconnect between students' expressed dissatisfaction with schooling inequality and their lack of willingness to alter the admissions process. The findings demonstrate how elite meaning-making serves to defend, maintain, and hence perpetuate their elite status. 


\section{Methodology}

This research is based primarily on 46 one-on-one in-depth, semi-structured interviews conducted with undergraduates attending Oxford University who had attended for at least two terms. ${ }^{\mathrm{v}}$ All respondents are British-born or arrived before age six. We interviewed 46 students in order to have some variability in students' backgrounds and experiences while simultaneously having time to conduct indepth, in-person interviews with each individual. 36 respondents have two British-born parents, and ten have at least one parent born outside the European Union. Students were recruited through emails sent to all undergraduates enrolled in two Oxford colleges, and were paid 15 pounds sterling to participate. All students who agreed to be interviewed were included in the study, and an effort was made to recruit students less inclined initially, by sending more than one message to residents of the colleges. The colleges are neither among the oldest Oxford colleges, nor among the newest colleges, and student performance at both colleges is within the middle 50\% of Oxford colleges (University of Oxford 2010d). While our sample is not meant to be representative of the Oxford student body, we chose to focus on colleges toward the median in terms of history and student performance so that we could investigate student perspectives that are likely to cut across numerous colleges.

Students were interviewed by one of the authors of this paper, a West European doctoral student at the time, for 1 to 2 hours each. Students also filled out a survey prior to the interview, which asked about their backgrounds (race/ethnicity, parents’ countries of origin, city of childhood, etc.), political identification, and their positions on a variety of political issues. Survey data was mainly used to understand students' social backgrounds and political perspectives in a short answer format. After interviews were transcribed and coded in ATLASti, we analyzed answers to the following questions for the analyses that follow:

(1) Would you say Oxford is a meritocracy in terms of its admissions? ? $^{\mathrm{vi}}$

(2) Less than $1 \%$ of Oxford students are black, but $2 \%$ of Britain's population is black. How do you explain this difference?

(3) Should the university do anything about the underrepresentation of black students? 
Twenty respondents attended privately-funded (independent) secondary schools, eight attended statefunded grammar schools, and eighteen attended state-funded non-grammar schools (graduates from both types of state-funded schools are referred to as state school graduates in the text unless otherwise suggested $)^{\text {vii }}$.

The distinction between state school graduates and private school graduates follows British public discourse on inequality with respect to university admissions. Public accusations of elitism at Oxford and Cambridge often cite the dearth of state school graduates (for example, see Vasagar 2010b). Recently, critics have cited the underrepresentation of black students, as well (for example, see Harris 2010; Parel and Ball 2013; Vasagar 2011). We chose to ask a question about black student underrepresentation for comparison to United States data, and because of recent controversies about the dearth of British black students at Oxford. Twenty-six respondents were women, and twenty men. Of the ten children of immigrants interviewed, three are black students whose parents are from Africa. The others have parents from Asia (6), the Middle East (1), and South America (1) ${ }^{\text {viii }}$.

The inclusion of a significant number of state-school graduates and children of immigrants allowed us to look carefully at these two groups and at whether they express significantly different answers to our interview questions. We expected to observe differences between children of immigrants and those with UK-born parents and between state- and private-school graduates with respect to perspectives on meritocracy, given their lack of history at Oxford and the overrepresentation of private school graduates at the university. However, we only found significant differences in the answers analyzed below between state- and private-school graduates, which this paper will draw upon where applicable.

\section{Findings}

\section{(1) Oxford Admissions and Meritocracy}

Oxford University became increasingly meritocratic after World War II in its admissions, but since the 1970s the strong competition for admission has led to an increase in the preponderance of 
private school graduates (Soares 1999). Candidates for study at Oxford apply to its colleges rather than to the university as a whole. The minimum criteria are three A grades in the A-level examinations (or the equivalent in a foreign system) and an on-campus interview held by tutors in the subject and college to which a candidate has applied (University of Oxford 2011a). Each subject also has different additional requirements for admission. Many require an A in the A-level exam of the subject; others require an Oxford-administered written exam such as the "Thinking Skills Assessment” which measures "skills and aptitude”; and others require a portfolio or written work to be submitted (University of Oxford 2011b). The listed criteria by which admissions tutors make decisions in the various subjects vary. For example, for Anthropology and Archeology, in addition to the A-level A grades, students must demonstrate an “ability to digest and assimilate significant quantities of data and argue from evidence”, and in their interview they “consider problems from archaeological and anthropological points of view” (University of Oxford 2010a). The biology department makes clear that they look for skills and interest rather than content knowledge of biology: "Interviews are designed to enable you to show your enthusiasm for biology and your ability to study. We are not testing your factual knowledge but your ability to think” (University of Oxford 2010b). Soares (1999) has shown that by the 1970s Oxford was significantly open to working class students, who were present, for example, in greater numbers at Oxford than at Harvard. Nevertheless, today $45 \%$ of Oxford students come from private schools, while $7.3 \%$ of British school students attend private schools (UK Department for Education 2010; University of Oxford 2011c).

When posed the question “would you say Oxford is a meritocracy in terms of its admissions?” 37 out of the 46 respondents (80\%) agreed. One private school graduate responded,

Um, that's what they say...Out of how many thousand applications, it's their job to get it down to the top $160 . .$. I know it's quite subjective in that you might have different views in that someone that is kind of--how do you distinguish between 159th and $161^{\text {st }}$--but that's what they are trying to do. They are trying to make it as fair as possible...They are not trying to play any tricks. They are not doing anything below the belt. It's in their interest to get the best 160 candidates that they can.

Note that this student, while expressing faith in the system, does acknowledge that some may critique it. The finding that most students support the admissions process is not surprising, given that those who have 
achieved within the competitive system have reason to perceive it to be a fair system. Still, the proportion was higher for private school graduates compared to students who came from state schools. Furthermore, 18 of the 46 respondents (nearly 40\%) mentioned unequal schooling as a mechanism by which othersespecially students from state schools — did not have the opportunity to meet the meritocratic standards that Oxford holds. For example, the student above noted that “obviously [Oxford] doesn't get that many applications from certain demographics so...there are, $60 \%$ of working class people in Britain, but there are only 40\% working class people in Oxford.” Some students both affirmed Oxford's meritocracy while also reporting unequal access, often via low-quality schooling. Here too we found a difference in the understandings of private and state school graduates: among all private school graduates, 25\% acknowledged inequality in schooling, while among all state school graduates who did not attend grammar schools, 55\% mentioned schooling inequality. This suggests that those who gained entrée despite their state-funded secondary education are more likely to see faults in the meritocratic system-in this case via schooling inequality—while those from private schools are more likely to overlook unequal access, suggesting that exposure to schooling inequalities personally may make state-school graduates more cognizant of inequalities in the system. Nevertheless, as this data demonstrates, most of these students did not connect the lack of equal schooling opportunities directly to a lack of fair chance to gain admission to Oxford, and hence to a fair chance to obtain elite status.

Both state and private school graduates citing unequal schooling asserted that state schools lack resources such as good teachers and preparation for exams and the Oxford admissions interview. For example, one state school graduate from London, the child of an immigrant mother, said,

Lots of [private] schools have people that... give you lots of interview practice and you get sent on courses, and other schools [state schools], they don't have anyone that goes here [Oxford] and you get sent without any preparation....Also in terms of grades, some schools are just better at getting good grades than other ones, and if you just aren't rich enough to get sent to one of those really good schools where they give you loads and loads of work-there are a lot of people who could be here but they can't just because they hadn't been trained well enough.

Some respondents particularly asserted that state schools do not encourage students to excel and interestingly to apply to Oxford, such as this white English student: 
I was lucky. My parents could afford to send me to a private school where, because I was quite intelligent, I was told by my teachers, 'You should be looking at Oxbridge. You should work hard. This is how you prepare.' And you get trained in that way of thinking, and some... friends who went to state schools were told, 'Don't bother applying to Oxford. It's for posh kids.' I've got friends who were actually discouraged from applying to Oxford who are now here.

This private boarding school graduate both acknowledges the disadvantages of his state-school peers while also asserting that he was "quite intelligent”, presumably a factor in his admission. Thus he both acknowledges the disadvantages that some students unlike himself face, while simultaneously asserting his qualification for being at Oxford as intelligence. This outlook resonates with those of many others who also identified inequality in schooling while also emphasizing belief in Oxford's meritocracy. In other words, to some, unequal outcomes based on unequal schooling was lamentable but did not compromise Oxford's meritocracy. For instance, this white private school graduate said,

From my experience the people that are admitted are based on how good they are rather than where they are from....but I think it's about $50 \%$ go to a [private] school who come here, but only about 3\% of people in England go to a [private] school. So it is a meritocracy but that meritocracy might be to do with the upbringing of the child.

Students like the one above believed that admissions should be based on criteria that are achieved more successfully through private school education (high national test grades, interview performance), because those are what constitute meritocracy.

These findings suggest that the students understood merit not only as intelligence and thus intellectual capabilities but also as constituted by skills, which they accepted to be cultivated most successfully in private schools and in middle- and upper-class families. This explains why some state school students could use their own admission as evidence of meritocracy. For example,

It proved to be a meritocracy for me because I went to a state school, and I'm an ethnic minority. So all these stereotypes that Oxford has, I kind of went against. So Oxford has a stereotype of admitting only private school children who are British and who are white and who are predominantly male as well. So being a female, Muslim, ethnic minority and from a state school, I kind of went against all of the stereotypes and still managed to get in...It does appreciate all people on their merit.

Like several others, this student still tempered her view of Oxford's meritocracy by recognizing the dearth of students from secondary schools like the ones they attended: 
...Then again there is also a huge ratio of private school to state school so I am not sure whether that's based on merit, because I'm not sure all private school children would be more intelligent than state school children, so I think there is a slight kind of bias towards them. But, I think it's getting better, definitely.

Such a qualification of an affirmative answer regarding whether Oxford is a meritocracy was common.

A minority who identified inequality in schooling argued that this inequality compromises Oxford's meritocracy. These students believed that merit is evenly distributed in the population, and so the disproportionate numbers of private school students indicated a problem. The $20 \%$ of students who said that Oxford is not a meritocracy either cited inequality in schooling or else pointed to peers whose parents also went to Oxford ${ }^{\mathrm{ix}}$. These families with a lineage of Oxford students were cited by three students who attended state schools, and by no private school students, suggesting that students from less traditional Oxford families were more likely to ascribe an elite character to the Oxford student body in terms of family background. These students were not sure about whether or how Oxford took legacy families into consideration, but they suspected it mattered. For example, one state school graduate whose grandparents were immigrants from Greece said,

A general thing that I just heard was that people from Oxford like to keep their own to their own. Sort of like if your parent was there, it's sort of a link; like when I was watching "The History Boys" one of the guys who got in, his dad went to the same college and he wasn't as good as all the others.

This student attended a state school in London. Assuming that his parents are not Oxford graduates, then acknowledging legacy preferences does not compromise his admissions achievement. He draws from popular culture — a movie — to understand how family connections to Oxford (and its colleges) supposedly advantage the children of Oxford graduates. Students citing the lack of meritocracy defined merit as potential to shine at Oxford, based on intelligence alone. For example, recall the student above who cited the overrepresentation of private school graduates as evidence of a lack of meritocracy, assuming that intelligence is evenly distributed in the population.

In sum, we found that most students acknowledged others' disadvantages in getting into Oxford and achieving the elite status it confers, but this understanding did not translate into an acknowledgment of their own advantages in status achievement. While a majority of students acknowledged that elite 
status can be cultivated, all of the students related their status achievement to their intelligence in one way or another. This allows them to maintain their sense of accomplishment of their status despite obvious inequalities and provides them with a rationale to perpetuate their status and with it the inequality of its attainment. This finding is even more pronounced in the following section, where students give explanations for the underrepresentation of black students at Oxford.

\section{(2) Explanations for black underrepresentation}

Recurrent outcries over the predominance of graduates of private secondary schools at Oxford (BBC News 2000; Shepherd 2010; Vasagar 2010b) have more recently been accompanied by highly visible public critiques by both an Afro-Caribbean Labour Member of Parliament (Lammy 2010) and Conservative Prime Minister David Cameron (Vasagar 2011) related to the underrepresentation of AfroCaribbean students at Oxford. In 2009, just one British Afro-Caribbean student was admitted, and the rate of admission for British Afro-Caribbean students was considerably lower than that of white British students (University of Oxford Equality and Diversity Unit 2010). These critiques suggest that Oxford admissions holds deep symbolic meaning for the British public. ${ }^{\mathrm{x}}$

Given these critiques, when students in our study were asked to explain why black students are underrepresented at Oxford, over half (57\%) argued that blacks are mainly part of the working class and thus are living in poor areas with poorly funded schools, which either do not prepare their pupils sufficiently for exams and the Oxford interview or do not encourage them to apply:

You get to Oxford as a result of your education. No matter how naturally brilliant you are, you have to be well educated. And, ...the wealth distribution in society means that white people have more access to the best education even in the state sector. The state schools are of a lower quality, in my belief, in areas of greater ethnic density.

This student attending a top British boarding school before Oxford.

Independent of minorities’ ability to come to Oxford due to low-quality schooling, nearly half of respondents believed that blacks are underrepresented at Oxford because they do not apply. They gave two kinds of reasons for their perceived low rates of application from black students ${ }^{\mathrm{xi}}$. First, some felt that Oxford's image as an elite, sometimes racist institution along with the paucity of black students on 
campus puts off black secondary school students from applying: “I don’t know if it’s Oxford’s image and stereotype, whether that's blocking people from going....There is this view of Oxford as being very kind of unattainable almost, if you're not white, posh, went to private school, things like that.” This student may have sympathized with a supposed cultural difference for black students. During his interview he described a teacher's encouragement to apply to Oxford at his rural state secondary school, despite his parents' lack of understanding of the admissions process or even the location of Oxford prior to the teacher's recommendation. His parents did not have post-secondary education.

Other students sympathized with an assumed disinterest in Oxford due to the lack of ethnic minorities on campus. One state school respondent who made this argument supported her idea by providing an example of a black friend of hers who did not apply to Oxford:

Well, from my personal experience, one of my friends at school was Black, and she gotshe had the grades to get into Oxford or Cambridge but she didn't even want to apply, because she was like: "There's not enough black people there so I don't want to go." So she went to Imperial ${ }^{\mathrm{xii}}$ in London to do Medicine. I think that's just what people think: "I'll be isolated because everyone will be white and I'll stand out because I'm black".

This white British student's mother works in the service industry and father as a transport driver. Although she felt Oxford should encourage students from working class and ethnic minority areas to apply, just as a teacher encouraged her to apply, she expressed strong opposition to class- or race-based preferences in admission.

Second, some believed that black students' family cultures were not conducive to academic success and interest in elite education. These students specifically identified black applicants, and argued that their lack of cultural focus on educational achievement prevents them from applying to and enrolling in elite universities like Oxford: "You could perhaps argue that among the black population there might be a greater percentage of problems like absentee fathers, or both parents working all the time so not having this opportunity to develop their child's intellectual interest.” This student is a private school graduate, and grew up in a neighborhood with high levels of education among adults and very low levels of socioeconomic disadvantage. Both of her parents are university graduates. Others pointed to cultural definitions of what is important: “From what I know there may be cultural pressures. If you're male and 
black, working and excelling academically is not the thing to be seen doing...” This student grew up in a neighborhood that is $97 \%$ white. The student's parents are university graduates who sent her to a private secondary school. Based on their secondary schools and childhood neighborhoods, both of the above quoted students are less likely to have had black peers growing up. In fact, four of the twenty private school graduates gave these kinds of cultural explanations for black underrepresentation, in contrast to just one each of graduates of grammar and non-grammar state schools. The evidence suggests that the lack of exposure makes private school graduates more likely to assert stereotypes about black British culture.

To sum up, most students explained the low numbers of black students at Oxford as related to either a cultural lack of interest or encouragement, which led to low numbers of applicants; or to class and subsequent school inequality that made black teens less prepared for admission to and study at Oxford. This again suggests that students view admission to Oxford as based on skills and cultures that are best cultivated in private schools and in privileged families. Furthermore, the findings suggest that those without personal exposure to social disadvantages, like graduates from private schools, are less likely to realistically identify problems faced by minorities in achieving elite status, as shown in the previous section.

Given the overall beliefs in meritocracy as well as the explanations for black disadvantage, what do students feel the university should do, if anything? Answers to this question, detailed below, illuminate the degree to which students are willing to change a process in which they were successful, in order to increase opportunities for others.

\section{(3) Maintaining Status}

In order to understand what actions students would be willing to have the university take to change the underrepresentation of black students, if anything, we asked, "Should the university do anything about the underrepresentation of black students?” The first question asks students open-endedly to suggest any changes at the university level that will presumably make the admissions process lead to a 


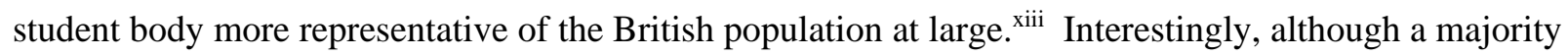
of students either qualified their answers to whether Oxford is a meritocracy or disagreed altogether, few when asked had suggestions for how the university could better include black students. One-third of students overall said that the university did not need to address this issue. For some of these respondents, the only solution they imagined was one they strongly disagreed with—-to take race/ethnicity into account in admissions. One-fourth specifically responded to the question by asserting their opposition to an admissions process that takes race or ethnicity into account. For example,

I know the college runs a tutoring scheme in Tower Hamlets...I think what they are doing is good, really, there is nothing wrong with it. I don't think they need to change any of the admissions systems to benefit certain ethnic minorities and make quotas and let them in on that basis.

This white student graduated from a state-funded grammar school. His family has a long history in the civil service. Like him, over one-third of our respondents felt that the university was doing enough already, sometimes mentioning Oxford's “access” schemes in which undergraduates recruit in schools from which Oxford typically does not receive applications.

Others felt that although unequal schooling leads to low proportions of black students (and state school graduates), it was not Oxford's responsibility to remedy this inequality at the secondary school level. For example, one graduate of an elite British boarding school said,

Yes, I do think [the underrepresentation of black students] is a problem, but Oxford doesn't represent the country. But I also think that there is only so much that Oxford can do about it, because if the situation in the country at large is such that students aren't sufficiently educated to be at Oxford, Oxford shouldn't dumb itself down purely to take on the burden of the country.

We quoted this student earlier, in his remarks about the importance of a solid education beyond intelligence as necessary for entrée to Oxford. Although students like him felt underrepresentation was undesirable, they thought that the university had already fulfilled its responsibility to attempt to change the profile of its student body, and that further changes by the university were not warranted.

The above responses indicating the university should do nothing, or nothing more than it already is, given by $74 \%$ of students overall, suggest that even while acknowledging inequality the students who 
have gained admission prefer to maintain the status quo. In other words, although they recognize others' disadvantages and lament them, they are leery of any policy that might disrupt admissions for students like themselves. Accordingly, our evidence suggests that to these students, maintaining a diverse student body did not qualify as an important institutional goal for the university. Nevertheless, maintaining the legitimacy of the admissions contest was important to them. To do this, the university needed to convince them that enough outreach had been made to underrepresented groups — and most students were convinced.

The finding that students could not think of and did not support suggested policies to decrease the social stratification they acknowledged to exist in admissions seemed to be motivated by the disconnect between their dissatisfaction with social inequality in the larger society and their lack of felt responsibility and willingness to alter the admissions process. Many students' responses to the question of whether the university should do anything about the underrepresentation of minorities at Oxford did not connect to their explanations for underrepresentation. For example, one grammar school graduate opined, "I think a lot of people who are black don't want to apply here because from what I hear at home like a lot of my friends who are of ethnic minority [background], they are really bright but they didn't want to apply here because they felt there weren't enough people like them.” This student later, when asked if the university should do anything about the lack of black students, said "I think they [Oxford] does enough.” If indeed the lack of minorities on campus prevents black students from applying, this student's suggestion will maintain the status quo of black underrepresentation. It is important to note that this student is the daughter of Asian immigrants who run a fast food establishment, so a family history of privilege cannot explain her perspective. Rather, she felt that making provisions for underrepresented groups like black students and state-school graduates would spoil the game: “as soon as you start trying to like do this [consider type of school or race in admissions] then you're not making it a fair sort of thing.” Her definition of fairness precludes compensatory practices.

Similarly, one private school graduate listed both structural and cultural reasons for the lack of black students at Oxford, invoking structural racism: "I think part of it is history...institutionalized racism 
possibly....I think part of the problem in black communities particularly is the lack of role models, and I think that's partly to do with the breakdown of the family.” Still, when asked to identify solutions, she strongly disagreed with race-based policies and stated that because Oxford has not caused disadvantage it should not take part in rectifying it:

I don't think that affirmative action is the answer because I think that...that's just a gesture towards what is actually a bigger problem within society. Those figures [on underrepresentation] are a manifestation of the problems facing the black community. I think most people would see that if you look at the ethnic diversity of Oxford, there are a fair number of-well mostly white students. There's also a fair representation of Asian students, but it's black students who seem to be underrepresented. And I think that is suggestive of greater problems within society, not Oxford's bias.

Because this private school graduate sees "structural racism” as a problem in the larger society rather than at Oxford, she places responsibility for change outside the gates of Oxford and does not include the university as part of the society that has perpetuated inequality. This interpretation resonates with the answers to a survey question based on underrepresented ethnic and racial minorities. For the survey statement "Underrepresented ethnic minorities should get special consideration in university admissions because they have experienced disadvantage in their lives” just 22\% of respondents agreed. This finding suggests that only a minority of students believe that the underrepresentation of disadvantaged groups can undermine that contest unless provisions are made for individuals who have suffered disadvantages. Although class defines social life in Britain to a greater extent than race, when asked a similar question regarding working class students only a minority agreed as well (38\%). In other words, despite an awareness of the inequality in access to Oxford by race and class, the majority of students advocated the maintenance of the admissions status quo. In this way, the disconnect between students' expressed dissatisfaction with schooling inequality and their lack of felt responsibility and willingness to alter the admissions process allows students to defend and maintain the legitimacy of their status.

\section{Conclusion}

In this paper we have detailed how students attending Oxford University understand their own elite status attainment through their admission to Oxford, their explanations of others' absence, and the 
extent to which the absence of others should be remedied. A majority of students believed that Oxford is meritocratic in its admission. Still, private school graduates were more likely than state school graduates to believe in Oxford's meritocracy. This finding suggests that those who gained entrée despite their statefunded secondary education are more likely to see faults in the meritocratic system-in this case via schooling inequality—while those from private schools are more likely to overlook unequal access.

Many students did believe that some schools—especially private schools—better prepare students to become "Oxford material” than others, accounting for the overrepresentation of advantaged students on campus. This was the case for both state- and private-school graduates. Although we expected that attending a state secondary school would make individuals more concerned about fairness, we surprisingly found that was not the case. ${ }^{\text {xiv }}$ Most state-school graduates, like their privately-educated counterparts, did not connect the lack of equal schooling opportunities directly to a lack of fair chance to gain admission to Oxford.

Thus, students defined meritocracy not only as intelligence but also as skills, which many acknowledged are best cultivated in private school settings. Students thus acknowledged others' disadvantages in getting into Oxford through their lack of access to the skills cultivated in high-quality schools, while maintaining that their own success in admission had to do with intelligence, seen as inherent to the individual. Their sense of accomplishment and self-worth derived from their selfidentified intelligence, which provided them with a solid and defensible rationale to overlook inequalities nurtured in the seemingly meritocratic system.

Furthermore, by affirming Oxford's meritocracy in admissions and recognizing the university’s outreach to underrepresented groups, most students thereby maintained the legitimacy of the admissions contest and thus preserved the legitimacy of their burgeoning elite status as Oxford undergraduates. Interestingly, this British way of making meaning of admission to an elite university resembles recent findings at US secondary boarding schools. Two recent studies of students attending elite American boarding schools find that most students believe that intelligence and hard work rather than privilege or parental influence afforded them the opportunity to study at elite high schools (Gaztambide-Fernandez 
2009; Khan 2010). Khan (2010) calls this a perspective of “democratic inequality”, in which "differences in outcomes are explained by the capacities of people” (page 196) while masking the durable inequality that a democratic inequality perspective perpetuates. This rationale allows students to maintain their sense of accomplishment and self-worth in a meritocratic system that cultivates inequality.

Still, as mentioned above, many did not gloss over the social inequality that leads to an overrepresentation of private school graduates and an underrepresentation of racial minorities at Oxford. When asked to explain the underrepresentation of black students at Oxford respondents cited class, culture, and schooling inequality. In this way, their views do not map onto a straightforward status reproduction model. In light of very public critiques of Oxford admissions, most students acknowledge a degree of inequality in secondary school quality, but just enough to maintain the legitimacy of the admissions process. These findings resonate with Jackman and Muha's (1984) analysis of the ways in which dominant groups in society maintain their advantage in the face of public critiques of inequality by defending the legitimacy of a system that led to their advantages. Jackman and Muha describe how dominant groups (1) privilege individual rights over group rights, much the way our respondents advocated individualistic, race- and class-blind assessments of candidates; and (2) advocate symbolic rather than substantive concessions, such as the Oxford outreach programs to disadvantaged youth that encourage underrepresented groups' applications to Oxford rather than policies that ensure their presence on campus.

Findings also showed that students had difficulty connecting unequal schooling, which many mentioned, to actions the university could take to help combat the underrepresentation of minorities. Most did not support any form of “compensatory sponsorship” (Grodsky 2007) through taking into account race or even social class in admissions, even though some admissions tutors at Oxford already practice an informal school-type version of compensatory sponsorship (Zimdars 2010). This support for the status quo in terms of policies while simultaneously acknowledging the disadvantages of others resonates with research in the United States analyzing white Americans' views on racial inequality. Specifically, white Americans often recognize African Americans’ disadvantages while disagreeing with 
social policies to remedy those disadvantages, such as affirmative action, aid to poor families with children, and busing to promote school integration; some have termed these views "new racism” (Bobo and Kluegel 1993; Quillian 2006; Schuman, Steeh, and Bobo 1997) for their expression of views that perpetuate minority disadvantages in society, in an era in which overt racism is no longer socially acceptable. Similarly, Americans often express support for multiculturalism in the abstract, but not for social policies to promote multiculturalism such as bilingual education (Citrin et al. 2001; Bell and Hartmann 2007). Much debate has considered whether these views are the result of feelings of group threat, individualized race prejudice from childhood, or political philosophy (Bobo and Kluegel 1993; Sears, Sidanius, and Bobo 2000; Sniderman and Carmines 1996). These studies employ large scale quantitative data to examine the correlation between policy preferences, feelings of group threat, and expressions of race prejudice. While such an analysis is not possible in our study, in this context we might assume that students' lack of support for compensatory measures have more to do with the British political landscape, which in turn shapes policies at Oxford University. Britain experienced no mass movement to combat racial discrimination, and does not have policies of affirmative action in higher education. Class shapes British individuals’ identities as well as how inequality is understood in British society, similar to the role that race plays in U.S. society. Furthermore, elite British universities have historically been “socially buffered” from British society, compared to elite US universities’ stronger ties to the state and local communities (Ramirez, 2006), and perhaps consequently not expected to play a role in stemming inequality of access based in children's unequal schooling experiences. Other research has shown that national context does indeed influence the degree to which individuals in society believe that the society functions as a meritocracy (Duru-Bellat and Tenret 2012). Origins aside, the lack of expectation that the university change and adapt to accommodate nontraditional students can assist in the maintenance of a static model of meritocracy at Oxford, and in this way can reproduce social inequality.

In the end, although many students acknowledged others’ disadvantages in getting into Oxford, most did not acknowledge their own advantages in their admission to Oxford. Through this perspective, students did not have to compromise the legitimization of their own status achievement based on merit. 
Given that a significant proportion of Oxford graduates will hold leadership roles in Britain in the future, such perspectives are likely to have noteworthy effects on decision-making on access and opening up elite education in Britain. Accordingly, our findings have significant societal relevance. We show how assumed future leaders place responsibility outside the gates of elite higher educational institutions. We have shown that not only institutions but also the individuals that institutions and gatekeepers reward have an interest in maintaining the legitimacy of the criteria for success in the institution.

Future research should further analyze elite status achievement from the perspective of elite individuals themselves in other domains, as we have shown that a look at individuals (in contrast to institutions (Bourdieu and Passeron 1977)), and a focus on meaning-making (in contrast to socialization or credentialing effects (Stevens, 2008)) provides a more nuanced understanding of how status may be perpetuated in society. In view of our findings, we also suggest that when scholars seek to understand the reproduction of status and in particular elite status, a look not only at what gains status but also at how those who attain elite status make meaning of their position, in the face of an unequal society, is insightful. 


\section{Works Cited}

Archer, Louise, Merryn Hutchings, and Alistair Ross. 2003. Higher education and social class: issues of exclusion and inclusion. London and New York: Routledge and Falmer.

BBC News. 2010. Chancellor attacks Oxford admissions 2000 [accessed 23 May 2011]. Available from http://news.bbc.co.uk/2/hi/uk_news/education/764141.stm .

Bell, Joyce M., and Douglas Hartmann. 2007. Diversity in Everyday Discourse: The Cultural Ambiguities and Consequences of “Happy Talk”. American Sociological Review 72 (6):895-914.

Blau, Peter Michael, and Otis Dudley Duncan. 1967. The American occupational structure. New York: Wiley.

Bobo, Lawrence, and James R. Kluegel. 1993. Opposition to race-targeting: Self-interest, stratification ideology, or racial attitudes? American Sociological Review 58 (4):443-464.

Bourdieu, Pierre. 1984. Distinction: a social critique of the judgment of taste. Cambridge: Harvard University Press.

Bourdieu, Pierre, and Jean-Claude Passeron. 1977. Reproduction in Education, Society and Culture. Translated by R. Nice. Vol. 5, SAGE Studies in Social and Educational Change London: SAGE Publications.

Bowles, Samuel, and Herbert Gintis. 1976. Schooling in capitalist America: educational reform and the contradictions of economic life. New York: Basic Books.

Citrin, Jack, David O. Sears, Christopher Muste, and Cara Wong. 2001. Multiculturalism in American Public Opinion. British Journal of Political Science 31 (2):247.

Collins, Randall. (1979). The Credential society : an historical sociology of education and stratification. New York: Academic Press.

Dalbert, Claudia. 2001. The justice motive as a personal resource : dealing with challenges and critical life events. New York: Kluwer Academic/Plenum Publishers.

Davies, Scott. 1995. Leaps of Faith: Shifting Currents in Critical Sociology of Education. American Journal of Sociology 100 (6):1448-1478.

Duru-Bellat, Marie, \& Tenret, Elise. 2012. Who's for Meritocracy? Individual and Contextual Variations in the Faith. Comparative Education Review, 56(2), 223-247.

Gaztambide-Fernandez, Rubén A. 2009. The best of the best: becoming elite at an American boarding school. Cambridge: Harvard University Press.

Grodsky, Eric. 2007. Compensatory Sponsorship in Higher Education. American Journal of Sociology 112:1662-1712.

Harris, Sir Martin. 2010. What more can be done to widen access to highly selective universities? Bristol, UK: Office for Fair Access.

Jackman, Mary R. and Michael J. Muha. 1984. Education and Intergroup Attitudes: Moral Englightenment, Superficial Democratic Commitment, or Ideological Refinement? American Sociological Review 49:751-769.

Kamens, David H. 1977. Legitimating Myths and Educational Organization: the Relationship between Organizational Ideology and Formal Structure. American Sociological Review 42 (2):208-219.

Karabel, Jerome, and A. H. Halsey. 1977. Power and ideology in education. New York: Oxford University Press.

Khan, Shamus Rahman. 2010. Privilege: the making of an adolescent elite at St. Paul's School. Princeton: Princeton University Press.

Lammy, David. 2011. The Oxbridge whitewash. The Guardian 2010 [accessed 23 May 2011]. Available from http://www.guardian.co.uk/commentisfree/2010/dec/06/the-oxbridge-whitewash-blackstudents .

Lerner, Melvin J. 1980. The belief in a just world : a fundamental delusion. New York: Plenum Press.

Lipset, Seymour Martin, and Reinhard Bendix. 1992. Social mobility in industrial society. New Brunswick: Transaction Publishers. 
Meyer, John W. 1977. The Effects of Education as an Institution. American Journal of Sociology, 83(1), 55-77.

Modood, Tariq. 1994. "Political Blackness and British Asians." Sociology 28:859-876.

Ogg, Tom, Anna Zimdars, and Anthony Heath. 2009. Schooling effects on degree performance: a comparison of the predictive validity of aptitude testing and secondary school grades at Oxford University. British Educational Research Journal 35:781-807.

Parel, Kurien and James Ball. 2013. Oxford University accused of bias against ethnic minority applicants. The Guardian, 26 February 2013, http://www.guardian.co.uk/education/2013/feb/26/oxford-university-ethnic-minority-applicants , accessed 21 March 2013.

Quillian, Lincoln. 2006. New Approaches to Understanding Racial Prejudice and Discrimination. Annual Review of Sociology 32 (1):299-328.

Ramirez, Francisco O. (2006). Growing Commonalities and Persistent Differences in Higher Education: Universities between Global Models and National Legacies. In H.-D. a. B. R. Meyer (Ed.), The New Institutionalism in Education (pp. 123-141). Albany: State University of New York Press.

Rawls, John. 1971. A theory of justice. Cambridge, Mass.,: Belknap Press of Harvard University Press.

Reay, Diane, Miriam E. David, and Stephen J. Ball. 2005. Degrees of choice: class, race, gender, and higher education. Stoke on Trent, UK and Sterling, USA: Trentham Books.

Reay, Diane, Gill Crozier, and John Clayton. 2009. "'Strangers in Paradise’?: Working-class Students in Elite Universities." Sociology 43(6): 1103-1121.

Schuman, Howard, Charlotte Steeh, and Lawrence Bobo. 1997. Racial attitudes in America: trends and interpretations. Cambridge: Harvard University Press.

Sears, David O., Jim Sidanius, and Lawrence Bobo. 2000. Racialized politics: the debate about racism in America. Chicago: University of Chicago Press.

Shepherd, Jessica. 2011. Oxford University admitted fewer state school pupils in 20092010 [accessed 23 May 2011]. Available from http://www.guardian.co.uk/uk/2010/mar/22/oxford-university-fewerstate-school-pupils .

Shiner, Michael, and Tariq Modood. 2002. Help or Hindrance? Higher Education and the Route to Ethnic Equality. British Journal of Sociology of Education 23 (2):209-232.

Sniderman, Paul M. and Edward G. Carmines. 1996. Beyond race: Social justice as a race neutral ideal. American Journal of Political Science 40:33.

Soares, Joseph A. 1999. The decline of privilege: the modernization of Oxford University. Stanford: Stanford University Press.

Stevens, Mitchell. 2008. Culture and Education. Annals of the American Academy of Political and Social Science 619:97-113.

Sutton Trust. 2012. The Educational Backgrounds of the Nation's Leading People [accessed 30 November 2012]. Available from http://www.suttontrust.com/research/the-educationalbackgrounds-of-the-nations-leading-people/ .

Teles, Steven M. 2001. "Positive Action or Affirmative Action? The Persistence of Britain's Antidiscrimination Regime." Pp. 241-269 in Color Lines: Affirmative Action, Immigration, and Civil Rights Options for America, edited by J. D. Skrentny. Chicago: University of Chicago Press.

UK Department for Education. 2010. Schools, Pupils and their Characteristics [accessed 30 May 2011]. Available from http://www.education.gov.uk/rsgateway/DB/SFR/s000925/index.shtml .

UK Department for Education. 2011. Schools, Pupils and their Characteristics [accessed 10 June 2012]. Available from http://www.education.gov.uk/researchandstatistics/statistics/statistics-bytopic/schoolpupilcharacteristics/a00196810/schools-pupils-and-their-characteristics-january-2 . University of Oxford. 2010a. Admissions: Archaeology and Anthropology--how to apply [accessed 2 August 2010]. Available from 
http://www.ox.ac.uk/admissions/undergraduate courses/courses/archaeology and anthropology/ archandanth 2.html .

—. 2010b. Biological Sciences Admissions and Application [accessed 14 July 2010]. Available from http://www.biology.ox.ac.uk/admissions_application.htm .

2010c. These issues are not just black and white [accessed 23 May 2011]. Available from http://www.ox.ac.uk/media/behind_the_headlines/101307.html .

2010d. Undergraduate Degree Classifications [accessed 13 January 2011]. Available from http://www.ox.ac.uk/about the_university/facts_and_figures/undergraduate_degr_2.html\#acolleg e_undergraduate_degree_classifications_200910_sorted_by_rank .

- 2011a. Entrance Requirements [accessed 27 May 2011]. Available from http://www.ox.ac.uk/admissions/undergraduate_courses/courses/courses_and_entrance_requirem ents/.

— 2011b. How to Apply: Tests [accessed 27 May 2011]. Available from http://www.ox.ac.uk/admissions/undergraduate courses/how to apply/tests/index.html .

— 2011c. Undergraduate admissions statistics: school type [accessed 30 May 2011]. Available from

http://www.ox.ac.uk/about_the_university/facts_and_figures/undergraduate_admissions_statistics /school type.html.

University of Oxford Equality and Diversity Unit. 2010. University of Oxford Race Equality Scheme 2009-2010: Annual progress report [accessed 13 January 2011]. Available from http://www.admin.ox.ac.uk/media/global/wwwadminoxacuk/localsites/equalityanddiversity/docu ments/race/racereport2010.pdf .

Vasagar, J. 2010. New Oxford school of governance will 'groom future world leaders'. The Guardian, 19 September 2010, http://www.guardian.co.uk/education/2010/sep/20/oxford-university-blavatnikschool-governance, accessed 6 June 2012.

- 2010. Save top university spaces for state school pupils, says Cable. The Guardian, 15 July 2010, http://www.guardian.co.uk/education/2010/jul/15/cable-university-state-school-places , accessed 20 July 2010.

— 2011. Oxford University and David Cameron clash over black student numbers. The Guardian, 11 April 2011, http://www.guardian.co.uk/education/2011/apr/11/oxford-cameron-blackstudents?INTCMP=SRCH, accessed 23 May 2011.

Weber, Max. 1968. Economy and society: an outline of interpretive sociology. New York: Bedminster Press.

Willis, Paul E. 1977. Learning to labour: how working class kids get working class jobs. Farnborough: Saxon House.

Young, Michael Dunlop. 1958. The rise of the meritocracy, 1870-2033: an essay on education and equality. London: Thames and Hudson.

Zimdars, Anna. 2010. Fairness and undergraduate admission: a qualitative exploration of admissions choices at the University of Oxford. Oxford Review of Education 36 (3):207-323.

Zimdars, Anna, Alice Sullivan, and Anthony Heath. 2009. Elite higher Education Admissions in the Arts and Sciences: Is Cultural Capital the Key? Sociology 43 (4):648-666. 


\section{Endnotes}

${ }^{i}$ On the other hand, some Oxford admissions tutors admit to considering school-type (state versus private) in their admissions decisions, in that they assume a state-school student with lower grades than one from an elite private school may have more potential to shine at Oxford (Zimdars 2010). These decisions seem to be wise, given research showing that for a given level of school performance state school graduates do better than private school graduates at Oxford (Ogg, Zimdars, and Heath 2009).

ii At the secondary level, Gaztambide-Fernandez (2009) and Khan (2010), in two recent ethnographies of elite American boarding schools, find that boarding school students believe that hard work and being smart are the critical drivers of their and their peers' admission to those elite high schools.

iii This "belief in a just world" (Lerner, 1980) has been shown by social psychologists to improve mental health and self-esteem (Dalbert, 2001). It is interesting to note that students' definitions of meritocracy do not align with the dominant view of moral philosophers, who suggest that if merit is inherent rather than earned it cannot be the basis for the social distribution of rewards - in this case, for admission to Oxford (Rawls, 1971).

iv We use the term "black" to suggest students of African descent, including Afro-Caribbeans and Africans. This is consistent with the daily usage of the term "black", which for most ethnic minorities in Britain does not include any Asian groups (Modood 1994). Asians, when taken as a whole, are not underrepresented at Oxford, although there is some evidence to suggest that Asians experience discrimination in admissions (Zimdars et al. 2009).

${ }^{\mathrm{v}}$ We excluded first year students because they had not fully experienced university life, an important topic for the project beyond this paper.

vi Some students asked what meritocracy means. They were told, "Meritocracy is a system in which achievement and success are based on merit rather than, for example, who your parents are, what school you went to, your class, who you know, etc.”

vii $6 \%$ of British primary and secondary students attend independent schools (UK Department for Education, 2011), and 42\% of students accepted to Oxford are from independent schools (University of Oxford, 2011c).

viii The total does not add up to ten because some students' parents were from different regions. Although we did not purposefully sample respondents whose parents come from particular regions of the world or who express particular racial identities, we did oversample for children of immigrants through follow-up emails seeking those with immigrant parents after our initial round of interviews.

ix Elite British universities do not have explicit policies to admit children of their graduates at higher rates or with weaker profiles than others. Nevertheless, it is a common perception that in fact attending Oxford or Cambridgeeven particular colleges within them-is done over generations in elite British families and that these elite universities and their colleges welcome and support these family legacies.

${ }^{x}$ The Oxford admissions office has disputed these critiques by claiming that the underrepresentation is due to AfroCaribbeans tending to choose the most highly selective subjects (medicine and law) (University of Oxford 2010c).

${ }^{x i}$ In reality, Afro-Caribbean students are more likely to apply than whites with the same number of A grades (University of Oxford 2010c). In fact, a lack of application alone cannot explain underrepresentation, because black students have lower rates of admission to Oxford. In 2009, for example, British-born black Caribbean students had a $2.9 \%$ success rate for admission, in contrast to the $27.6 \%$ success rate for white applicants (University of Oxford Equality and Diversity Unit 2010). This, in addition to black students being less likely to apply to Oxford, led to just one British-born Afro-Caribbean student being admitted to Oxford in 2009, out of 34 applicants. British AfroCaribbean students' propensity to select the most competitive subjects, including medicine and law, may explain some of this difference (University of Oxford. 2010c).

xii After Oxford and Cambridge, Imperial is Britain’s highest ranking university for the sciences.

xiii Although the UK Race Relations Act of 1976 prohibits "positive discrimination”, it allows for "positive action" in Britain. On the surface this suggests that any kind of preference for racial minorities is not allowed in admissions. However, the United States Civil Rights Act similarly prohibits racial discrimination, yet certain forms of affirmative action for racial minorities in higher education admissions have been implemented and then challenged in the courts and, in some cases, allowed, under particular legal interpretations. For multiple social, cultural, and political reasons beyond the legal question, racial considerations in university admissions (as well as in hiring) have not been implemented in Britain, but it is possible that such considerations could withstand legal challenges (Teles, 2001). 
xiv Reay and her colleagues (2009) have shown that working class students do articulate cultural boundaries between themselves and more advantaged peers at an elite British university. 